\title{
Histochemical demonstration of chymotrypsin like serine esterases in mucosal mast cells in four species including man
}

\author{
JF HUNTLEY, GFJ NEWLANDS, S GIBSON, ANNE FERGUSON, ${ }^{*}$ HRP MILLER \\ From the Moredun Research Institute, Edinburgh, and the * University of Edinburgh, Gastro-Intestinal Unit, \\ Western General Hospital, Edinburgh
}

SUMMARY Serine esterases were detected in the granules of mucosal mast cells from rat, mouse, sheep, and man. Successful demonstration of enzyme activity required brief fixation $(6 \mathrm{~h})$ of tissues in $4 \%$ paraformaldehyde. Staining with naphthol AS-D chloroacetate produced an intense red reaction product in intraepithelial mucosal mast cells (globule leucocytes) and mucosal mast cells within the lamina propria of the gastrointestinal tract. The mast cell identity of cells stained for esterase was confirmed by sequential staining with toluidine blue ( $\mathrm{pH} 0 \cdot 5)$. Furthermore, the numbers of cells detected after staining for esterases or with toluidine blue were highly correlated. Esterase activity within mucosal mast cells/globule leucocytes from all species was inhibited with the serine enzyme inhibitor phenylmethylsulphonyl fluoride. Further histochemical studies with the substrate, $\mathrm{N}$-acetyl-DL-phenylalanine B-naphthyl ester, indicated that mucosal mast cells and globule leucocytes contain esterases which are chymotrypsin like in substrate specificity.

Mucosal mast cells have been implicated in a range of diseases and allergic disorders in man, as well as in immunity to helminth infections in both laboratory and domestic animals.' In the rat, mucosal mast cells and intraepithelial mucosal mast cells (known as globule leucocytes) have been extensively studied and shown to have various unique properties. Rat mucosal mast cells differ biochemically and functionally from connective tissue mast cells, ${ }^{2}$ and mucosal mast cells in rat and man contain granules which require special fixation techniques to be detected..$^{34}$ This probably reflects the composition of the granule matrices, which is different from those in connective tissue mast cells. In particular, rat mucosal mast cells contain a distinctive chymotrypsin like serine protease (RMCPII) which is antigenically distinct from a similar enzyme found in connective tissue mast cells. ${ }^{5}$ The finding that RMCPII is released systemically during intestinal anaphylaxis ${ }^{6}$ and nematode infections ${ }^{7}$ in the rat has provided a further stimulus to investigations into the biological role of mucosal mast cells. The measurement of RMCPII has thus enabled a sensitive and

Accepted for publication 18 December 1984 non-invasive method to monitor in vivo functions of a defined mast cell population. These studies have been confined to the rat, however, and it was therefore considered important to examine whether similar mucosal mast cells enzymes are present in other species, including man. Previous studies have used esterase substrate to localise enzymes within connective tissue mast cells from several species. ${ }^{89} \mathrm{We}$ have therefore investigated enzyme histochemical methods for the demonstration of esterases within mucosal mast cells of rat, mouse, sheep, and man. This paper describes the application of an enzyme histochemical technique for mucosal mast cell esterases, which was assessed as a quantitative method for the enumeration of mucosal mast cells in the four species.

\section{Material and methods}

\section{ANIMALS AND TISSUES}

In order to provoke mucosal mastocytosis and the generation of intraepithelial mucosal mast cells (globule leucocytes) rats, mice, and sheep were infected with nematode parasites. 
Rat

Adult male Wistar rats were bled out under ether anaesthesia and lengths of jejunum $(0.5 \mathrm{~cm})$ were taken from animals which had received 3000 third stage Nippostrongylus brasiliensis larvae $\left(\mathrm{l}_{3}\right) 16$ days previously and from normal rats.

\section{Mouse}

Outbred S/Swiss mice kept in a closed colony at the Moredun Institute were used. Jejunal tissue was taken from mice which had received 200 mouse adapted Nippostrongylus brasiliensis larvae $\left(l_{3}\right) 16$ days previously.

\section{Sheep}

Eight month old Suffolk cross lambs out of Greyface ewes were used. Abomasal (fourth stomach) tissue was taken from normal sheep and from animals which had received 10000 Ostertagia circumcincta $1_{3}$ /day 10 weeks before sacrifice.

\section{Human}

Small operative biopsy specimens of normal jejunum were obtained from patients undergoing abdominal surgery at the Western General Hospital, Edinburgh. In all cases the intestine had been incised for resection or for creation of an anastomosis. Tissue specimens were rinsed in cold saline and placed in Carnoy or paraformaldehyde fixative within $10 \mathrm{~min}$.

\section{FIXATIVES}

1. BLA (Mota's basic lead acetate acetic acid ethanol: $1 \mathrm{~g}$ of basic lead acetate, $50 \mathrm{ml}$ of ethanol, $50 \mathrm{ml}$ of distilled water, $0.5 \mathrm{ml}$ of glacial acetic acid). ${ }^{\prime \prime}$ Fixation time $24 \mathrm{~h}$ at $4^{\circ} \mathrm{C}$.

$24 \%$ paraformaldehyde in phosphate buffered saline, $\mathrm{pH} 7 \cdot 4 .^{12}$ Fixation time $6 \mathrm{~h}$ or $24 \mathrm{~h}$ at $4^{\circ} \mathrm{C}$.

3 Modified Karnovsky's fixative: $4 \%$ paraformaldehyde, $3 \%$ glutaraldehyde in $0.05 \mathrm{M}$ phosphate buffer, $\mathrm{pH} 7 \cdot 4 . .^{13}$ Fixation time $6 \mathrm{~h}$ or $24 \mathrm{~h}$ at $4^{\circ} \mathrm{C}$.

\section{PREPARATION OF TISSUES}

Paraffin sections

After fixation, intestinal tissues were trimmed to give longitudinal sections, dehydrated in graded ethanol series at $4^{\circ} \mathrm{C}$, and embedded in paraffin wax with minimal heating. Sections were cut at $5 \mu \mathrm{m}$, deparaffinised in xylene, hydrated through graded ethanols to water, and stained. Abomasal folds were trimmed and prepared as described previously. ${ }^{10}$

\section{Prefixed frozen sections}

After fixation, mouse, rat, and sheep tissues were transferred to $3 \%$ dimethylsulphoxide (Sigma) for a further $1 \mathrm{~h}$ at $4^{\circ} \mathrm{C}$. Small pieces of tissue were frozen rapidly on a solid copper chuck precooled in dry ice/isopentane, and sections were cut in a cryostat (Frigocut, Reichert-Jung).

\section{Postfixed frozen sections}

Small pieces $\left(1 \mathrm{~mm}^{2}\right)$ of fresh mouse, rat, and sheep tissues were frozen rapidly on a solid copper chuck precooled in dry ice/isopentane and sectioned immediately in a cryostat. Sections fixed in cold Karnovsky's fixative, $4 \%$ paraformaldehyde, or BLA for $10 \mathrm{~min}$ at $4^{\circ} \mathrm{C}$ were rinsed three times in phosphate buffered saline before staining.

\section{HISTOCHEMICAL STAINING FOR MAST CELL}

\section{ESTERASES}

Three methods were investigated:

1 Sections were stained with the substrate, naphthol AS-D chloroacetate (NASDCA) (Sigma), as described by Seppa. ${ }^{14}$ The incubation medium consisted of $(a) 0 \cdot 1 \mathrm{M}$ potassium phosphate, $\mathrm{pH} \mathrm{6.0;} \mathrm{(b)}$ freshly prepared and filtered Fast Garnet GBC salt (Sigma) $(2 \mathrm{mg} / \mathrm{ml})$ in buffer $(a)$; and (c) NASDCA $(5 \mathrm{mg} / \mathrm{ml})$ in dimethylsulphoxide. All three were mixed in the proportions of 60:20:1 respectively and filtered before use. Staining was for $30 \mathrm{~min}$ and, after excess stain had been removed with water, sections were mounted in polyvinylpyrrolidone.

2 Staining with the substrate naphthol AS phenyl-propionate (NASPP) (Sigma) was as described by Langunoff and Benditt. ${ }^{15}$ Fast Garnet GBC salt ( $5 \mathrm{mg}$ ) was added to a solution containing $2 \mathrm{ml}$ of methanol, $4 \mathrm{ml}$ of $0.2 \mathrm{M}$ Tris buffer, $\mathrm{pH} 8.0$, $1 \mathrm{ml}$ of $0.03 \mathrm{M} \mathrm{CaCl}_{2}$, and $3 \mathrm{ml}$ of $\mathrm{H}_{2} \mathrm{O}$. The solution was mixed rapidly, filtered, and added to $0.5 \mathrm{ml}$ of 1 mM NASPP in methanol. The stain was used immediately, and sections were stained for $30 \mathrm{~min}$ and then rinsed in water and mounted in polyvinylpyrrolidone.

3 The method of Burstone ${ }^{16}$ for esterases was modified for the demonstration of the esterase enzymes of mast cells. Fifteen milligrams of either NASDCA or N-acetyl-DL-phenylalanine B-naphthyl ester (NAPNE) (Sigrna) was dissolved in $2 \mathrm{ml}$ of dimethylformamide (BDH chemicals) and to this solution $5 \mathrm{ml}$ of ethylene glycol monoethyl ether (BDH), $10 \mathrm{ml}$ of $0.2 \mathrm{M}$ tris-maleate buffer, $\mathrm{pH} 7 \cdot 5$, and $8 \mathrm{ml}$ of distilled water were added. This substrate solution was mixed with $15 \mathrm{mg}$ Fast Garnet GBC salt and immediately filtered through a $0.22 \mu \mathrm{m}$ millipore membrane on to the sections, which were stained for $5 \mathrm{~min}$, washed with distilled water, and mounted in polyvinylpyrrolidone.

For control purposes the substrate was omitted and sections were incubated in substrate buffer with Fast Garnet GBC salt. 


\section{IDENTIFICATION OF ESTERASE CONTAINING}

\section{CELLS}

To identify esterase positive cells, sections of all species were first stained for enzyme with NASDCA, as described in method $\mathbf{3}$. The cells were photographed, after which stain was removed from the cells by sequential dehydration in alcohol and xylene. After rehydration the sections were stained with toluidine blue, $\mathrm{pH} 0.5$, or alcian blue ( $\mathrm{pH} 0 \cdot 3$ ). Toluidine blue was a $0.5 \%$ aqueous solution in 0.5 $\mathrm{N}$ hydrochloric acid, $\mathrm{pH} \mathbf{0 . 5}$, and sections were stained for $30 \mathrm{~min} .{ }^{17}$ Alcian blue was an $0.1 \%$ aqueous solution in $0.7 \mathrm{M}$ hydrochloric acid, $\mathrm{pH} 0.3$, and sections were stained for $1 \mathrm{~h} .{ }^{17}$

\section{QUANTITATION OF CELLS}

Four to six blocks of tissue were obtained from a minimum of four individuals from each of the following groups: normal rats, infected rats, normal sheep, infected sheep, infected mice, and human patients. From each block four to five sections were prepared and the numbers of esterase containing cells were determined by counting stained cells within the area $\left(0.11 \mathrm{~mm}^{2}\right)$ defined by a calibrated eyepiece graticule. For intestinal tissue, the edge of the graticule was orientated along the muscularis as previously described, ${ }^{5}$ and with sheep abomasal tissue the top edge of the graticule was orientated along the epithelial surface. On each section the number of stained cells within five areas was counted and, for each individual, expressed as the number of cells per square millimetre.

For the enumeration of mucosal mast cells, sections adjacent to those stained for esterase were stained with toluidine blue, $\mathrm{pH} 0 \cdot 5,{ }^{17}$ and counts were performed as described for esterase stained cells. The fields encompassed by the graticule were selected to correspond with those chosen for esterase cell counts. Mucosal mast cell counts, including globule leucocytes, were expressed as the number of cell per square millimetre.

\section{STATISTICAL METHODS}

Simple regression analysis was performed on the data using a Tektronix microcomputer.

\section{INHIBITION STUDIES}

The inhibition of esterase staining with the serine esterase inhibitor phenylmethylsulphonyl fluoride was investigated. Sections were incubated overnight at $4^{\circ} \mathrm{C}$ in $2 \mathrm{mM}$ or $4 \mathrm{mM}$ phenylmethylsulphonyl fluoride dissolved in the substrate buffer solution as described in method 3. Control sections were incubated in substrate buffer alone. After incubation, sections were stained for enzyme as described in method 3.

The following inhibitors ${ }^{18}$ were also investigated on sections of human and sheep tissues: soybean trypsin inhibitor type 1-S (Sigma) $1 \mathrm{mg} / \mathrm{ml}$; chicken egg white ovoinhibitor type IV-O (Sigma) $1 \mathrm{mg} / \mathrm{ml}$; L-1-tosylamide-2-phenylethyl chloromethyl ketone (Sigma) $0.35 \mathrm{mg} / \mathrm{ml}$; and N-P-tosyl-L-lysine chloromethyl ketone (Sigma) $0.35 \mathrm{mg} / \mathrm{ml}$. All inhibitors were dissolved in substrate buffer solution at the concentration shown, and sections were preincubaied for $\mathbf{3 0}$ minutes before enzyme staining. Inhibitors were also incorporated in the substrate solution during staining.

Table 1 Esterase staining of mast cells with naphthol AS-D chloroacetate in tissues fixed for $24 h$

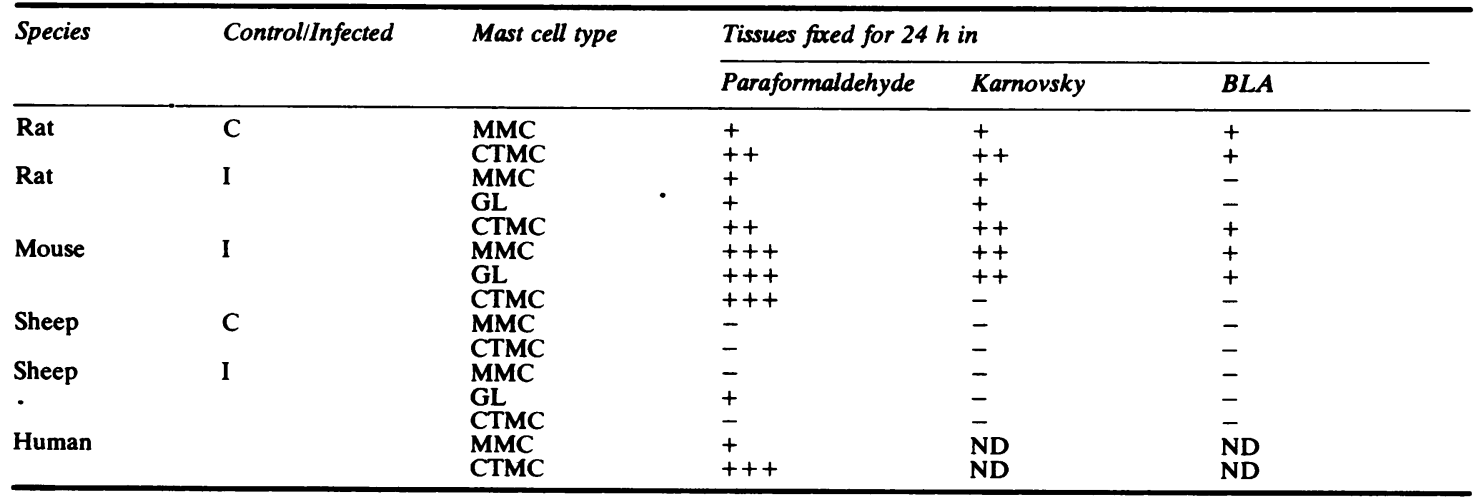

Intensity of staining: - no staining, + weak, ++ moderate, +++ intense.

$\mathrm{ND}=$ not done.

BLA = Mota's basic lead acetate acetic acid ethanol.

Tissues from human and from control (C) or nematode infected (I) rats, mice, or sheep were fixed for $24 \mathrm{~h}$ and sections stained with naphthol AS-D chloroacetate and Fast Garnet GBC salt. The histochemical reaction within mucosal mast cells (MMC), globule leucocytes (GL), and connective tissue mast cells (CTMC) is shown for each fixative. MMC and GL were present in the mucosa whereas CTMC were detected in the serosa in rodents and in the submucosa in sheep and man. 
Table 2 Esterase staining of mast cells in tissue foxed for $6 \mathrm{~h}$ in paraformaldehyde

\begin{tabular}{|c|c|c|c|c|c|}
\hline \multirow[t]{2}{*}{ Species } & \multirow[t]{2}{*}{ Control/Infected } & \multirow[t]{2}{*}{ Tissue } & \multirow[t]{2}{*}{ Mast cell type } & \multicolumn{2}{|c|}{ Staining of cells } \\
\hline & & & & NAPNE & $N A S D C A$ \\
\hline Rat & $\mathrm{C}$ & Jejunum & $\begin{array}{l}\text { MMC } \\
\text { CTMC }\end{array}$ & $\begin{array}{l}++ \\
++\end{array}$ & $\begin{array}{l}+++ \\
+++\end{array}$ \\
\hline Rat & I & Jejunum & $\begin{array}{l}\text { MMC } \\
\text { GL } \\
\text { CTMC }\end{array}$ & $\begin{array}{l}++ \\
++ \\
++\end{array}$ & $\begin{array}{l}+++ \\
+++ \\
+++\end{array}$ \\
\hline Mouse & I & Jejunum & $\begin{array}{l}\text { MMC } \\
\text { GL } \\
\text { CTMC }\end{array}$ & $\begin{array}{l}++ \\
++ \\
+\end{array}$ & $\begin{array}{l}+++ \\
+++ \\
++\end{array}$ \\
\hline Sheep & $\mathrm{C}$ & Abomasum & MMC & + & + \\
\hline Sheep & I & Abomasum & $\begin{array}{l}\text { MMC } \\
\text { GL } \\
\text { CTMC }\end{array}$ & $\begin{array}{l}+ \\
+ \\
-\end{array}$ & $\begin{array}{l}+ \\
+ \\
+\end{array}$ \\
\hline Human & & Intestine & $\begin{array}{l}\text { MMC } \\
\text { CTMC }\end{array}$ & + & $\begin{array}{l}++ \\
+++\end{array}$ \\
\hline
\end{tabular}

Intensity of staining: - no staining, + weak, ++ moderate, +++ intense.

Sections from human and from control (C) or nematode infected (I) rat, mice, or sheep gastrointestinal tissues fixed for $6 \mathrm{~h}$ with $4 \%$ paraformaldehyde and stained with substrates naphthol AS-D chloroacetate (NASDCA) or N-acetyl-DL-phenylalanine B-naphthyl ester (NAPNE) together with Fast Garnet GBC salt. The histochemical reaction within mucosal mast cells (MMC), globule leucocytes (GL), and connective tissue mast cells (CTMC) is shown for each substrate.

\section{Results}

Initial investigations of mucosal mast cell esterases, using methods 1 and 2, were unsuccessful. Sections of tissues fixed in either Karnovsky's, paraformaldehyde, or BLA fixatives showed little or no evidence of staining in mucosal mast cells.

The method of Burstone ${ }^{16}$ was therefore investigated. The substrate, napthol AS-LC proprionate, recommended in the original technique was substituted with the substrate NASDCA, which has been shown to hydrolyse chymotrypsin like enzymes. ${ }^{19}$ In postfixed frozen sections no staining was observed in the three species examined. In prefixed frozen sections, although staining was observed, the reaction product was diffuse, resulting in poor localisation of the cells. The results on sections from paraffin embedded tissues fixed for $24 \mathrm{~h}$ in either paraformaldehyde, Karnovsky's or BLA were much more satisfactory and are summarised in Table 1. Fixation with paraformaldehyde provided optimal preservation and localisation of enzyme activity in the granules of mouse mucosal mast cells and globule leucocytes. In this species an intense red reaction product was observed with mucosal mast cells and globule leucocytes. Enzyme histochemical staining in sections of sheep, rat, and human tissues also indicated that paraformaldehyde was the fixative of choice (Table 1). In these species, however, the staining of mucosal mast cells/globule leucocytes was less intense with poor localisation of reaction product. In order to improve localisation and intensity of stain, the effect of brief $(6 \mathrm{~h})$ immer- sion of tissues in paraformaldehyde was investigated.

\section{SIX HOUR FIXATION WITH}

PARAFORMALDEHYDE

The staining obtained with NASDCA and Fast Garnet GBC salt in tissues from the four species are summarised in Table 2. Sequential staining of sections stained for esterase and subsequently with toluidine blue ( $\mathrm{pH} 0.5)$ provided direct evidence for the identity of the esterase containing cells. In the four species studied all the cells which stained intensely for esterase were identified as mucosal mast cells, globule leucocytes or connective tissue mast cells.

\section{Mouse}

Mucosal mast cells and globule leucocytes stained intensely, with excellent localisation of esterase activity in the cytoplasmic granules (Fig. 1). Although connective tissue mast cells were clearly visible, staining of these cells was generally less intense than in mucosal mast cells or globule leucocytes. In addition to connective tissue mast cells, staining was also seen in a further population of cells within the connective tissue of the sub-mucosa. These cells, unlike mast cells, contained only a few pale stained granules and were readily distinguished from the more intensely stained connective tissue mast cells. Light staining within goblet cells was also observed. 


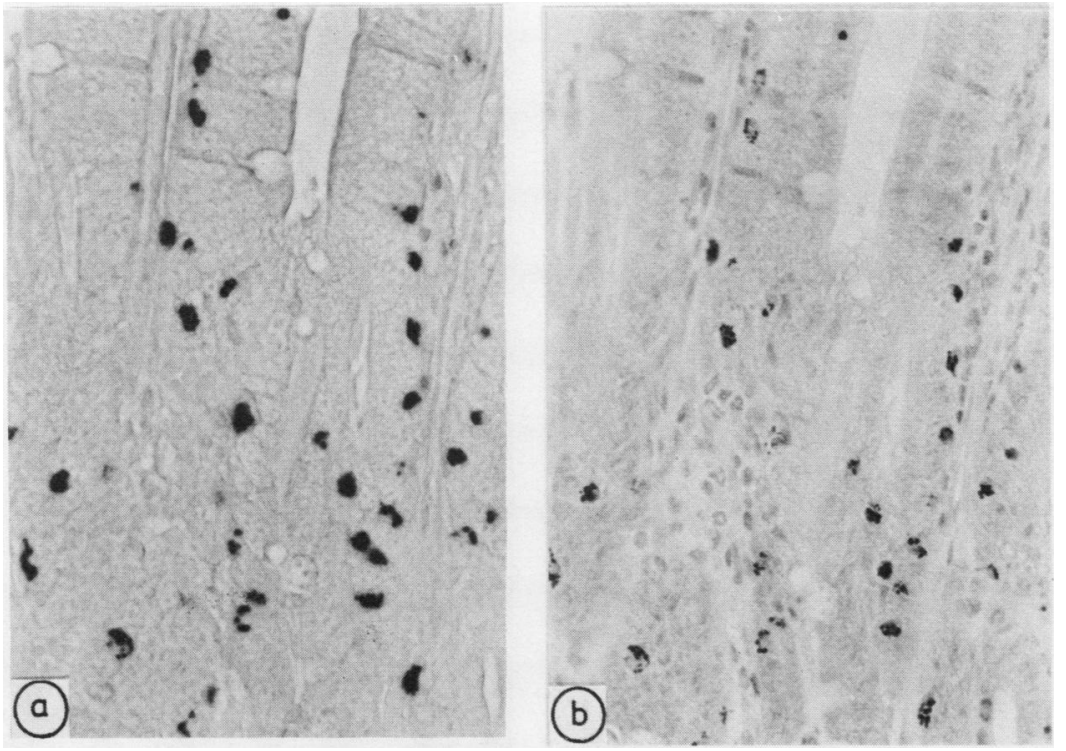

Fig. 1 (a) Section of immune mouse jejunal tissue, stained with naphthol AS-D chloroacetate and Fast Garnet GBC salt. Note the intense staining of the esterase positive cells. $\times 250$. (b) After destaining of the section shown in (a) the same section was stained with toluidine blue (pH 0.5), thus confurming the mucosal mast cell/globule leucocyte identity of the cells containing serine esterase $(s) . \times 250$.

Rat

Staining was confined to mucosal mast cells, globule leucocytes, and connective tissue mast cells in normal or immune rats and the intense red coloured reaction product was localised within the granules.

\section{Human}

Mucosal mast cells stained moderately intensely (Fig. 2), and, although in general the localisation of the reaction product was good, a few cells showed some diffusion of enzyme activity. As in the mouse, weak staining was also noted in a non-mast cell population of cells predominantly within the blood vessels of the sub-mucosa, which were subsequently identified as neutrophils. Light brown staining was also seen in the basal region of enterochromaffin cells. This was a non-specific reaction, however, since similar coloration of these cells was observed in control sections stained with Fast Garnet azo dye alone.

\section{Sheep}

Globule leucocytes in the abomasa of immune sheep stained moderately well, with good localisation of the red reaction product within the globules (Fig. 3). Mucosal mast cells in these animals stained less intensely (Fig. 3), and some diffusion of reaction product was observed. Only a few weakly stained mucosal mast cells were seen in abomasa from normal sheep. No staining within connective tissue mast cells or other cells was noted (Table 2).

\section{QUANTITATIVE STUDIES}

Comparisons, by regression analysis, of the numbers of cells stained with esterase and of mucosal mast cells and globule leucocytes stained with toluidine blue, $\mathrm{pH} 0.5$, are shown for each species in Fig. 4. These comparisons in mouse, rat, man, and immune sheep were highly significant $(p<0.001)$, indicating that the majority of esterase stained cells were mucosal mast cells and globule leucocytes. In normal sheep, regression analysis as well as sequential staining showed that while all esterase stained cells were mucosal mast cells, only a proportion of these cells were esterase positive (Fig 4).

\section{OPTIMAL PH FOR STAINING REACTION}

Since enzyme reactions are critically dependent on $\mathrm{pH}$, the effect of varying $\mathrm{pH}$ for the histochemical demonstration of mucosal mast cell esterases was investigated. Sections from paraffin embedded human intestine and immune sheep abomasal tissue, 

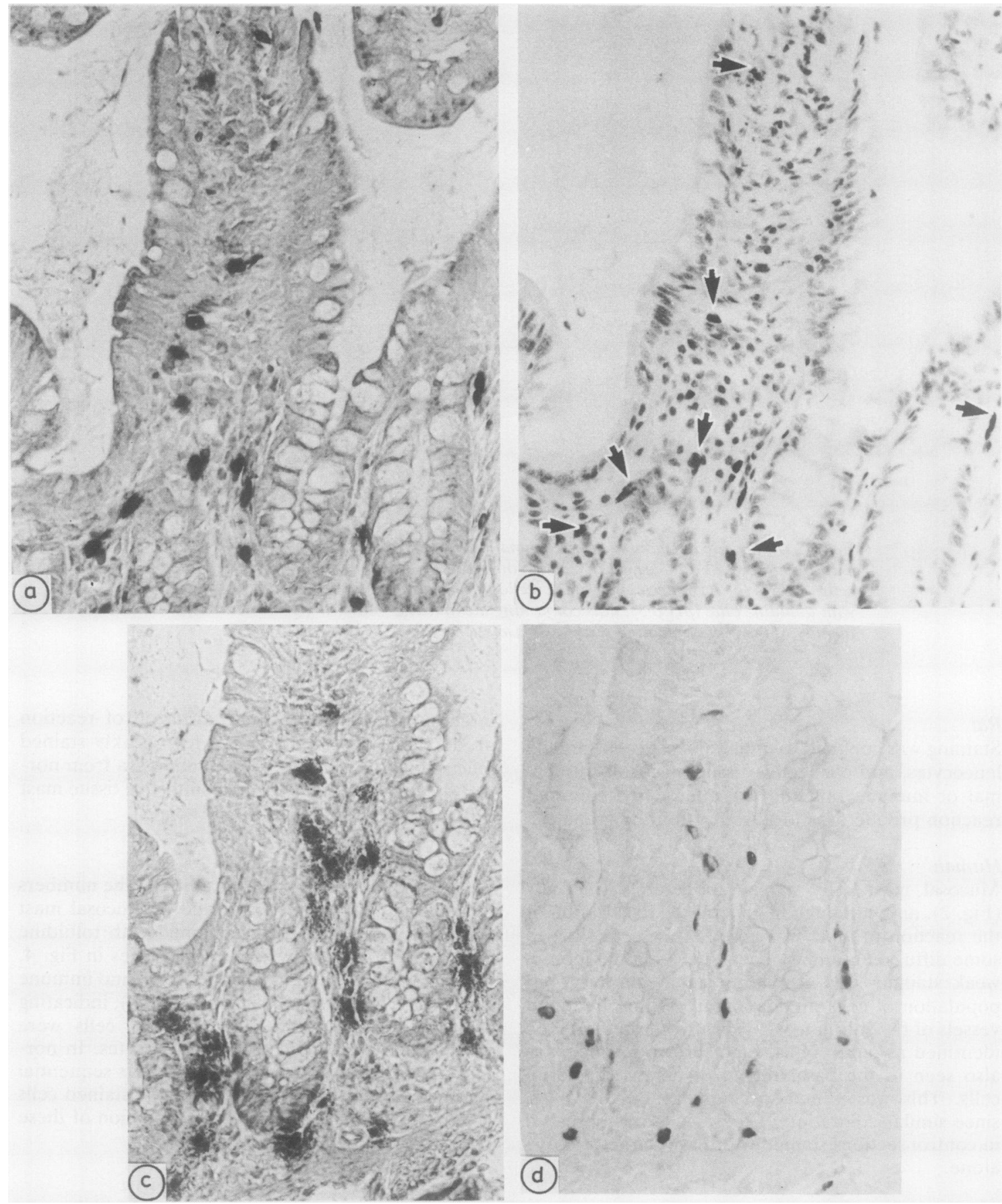

Fig. 2 (a) Section of human intestinal tissue, stained with naphthol AS-D chloroacetate and Fast Garnet GBC salt, showing the intense staining of cells containing serine esterase(s) within the mucosa. $\times 400$. (b) After the destaining of the section shown in (a) the same section was stained with toluidine blue ( $\mathrm{pH} 0.5)$. The mucosal mast cells (arrowed) correspond with those cells stained for esterase and confirm the mucosal mast cell identity of the cells containing serine esterase(s). $\times$ 400. (c) Photomicrograph of an adjacent section to that shown in (a) and stained for chymotrypsin like serine esterases with the substrate $N$-acetyl-DL-phenylanaline B naphthyl ester and Fast Garnet GBC salt. Although the staining was diffuse with poor localisation of reaction product, the distribution of stained cells was similar to that shown in (a). $\times 400$. (d) After destaining of $(c)$ the same section was stained with alcian blue and shows the mucosal mast cell identity of cells containing chymotrypsin like esterase $(s) . \times 400$. 


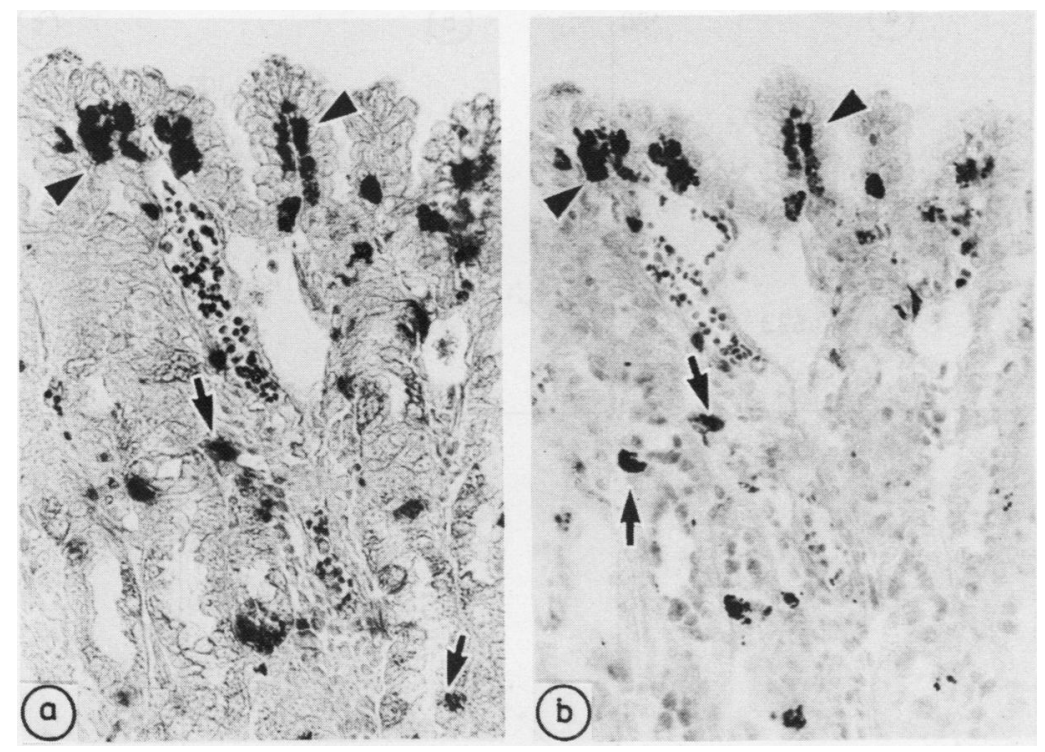

Fig. 3 (a) Section of abomasum from an immune sheep stained with naphthol $A S-D$ chloroacetate and Fast Garnet GBC salt. Note the intensely stained globule leucocytes (arrowheads), and less intensely stained mucosal mast cells (arrows). $\times 250$. (b) Section (a) stained with toluidine blue ( $\mathrm{pH} \mathrm{0.5),} \mathrm{confirming} \mathrm{the} \mathrm{mucosal} \mathrm{mast} \mathrm{cell}$ (arrows)/globule leucocyte (arrowheads) identity of the esterase stained cells. $\times 250$.

previously fixed for the optimal period of $6 \mathrm{~h}$ in paraformaldehyde, were stained with NASDCA and Fast Garnet GBC salt. The effect on the staining reaction of tris-maleate buffers of $\mathrm{pH} 7 \cdot 1,7 \cdot 5,8 \cdot 0$, and 8.5 was examined and the results are summarised in Table 3. Optimal staining for both species was obtained at $\mathrm{pH} 7 \cdot 5$.

\section{INHIBITORS}

When compared with control sections, staining of human and sheep mast cells with NASDCA and Fast Garnet GBC salt in the presence of soybean trypsin inhibitor type I-S, chicken egg white ovoinhibitor type IV-o, L-1-tosylamide2-phenylethyl chloromethyl ketone, and $\mathrm{N}$ P-tosyl-L-lysine chloromethyl ketone was undiminished. Total inhibition of mast cell staining, however, was achieved when sections from sheep and human tissues were preincubated with $2 \mathrm{mM}$ phenylmethylsulphonyl fluoride. Some staining of mast cells remained in rat and mouse sections incubated with the inhibitor, but this was totally abolished after treatment with $4 \mathrm{mM}$ phenylmethylsulphonyl fluoride.

\section{STAINING WITH NAPNE}

A further esterase substrate, NAPNE, was substituted for NASDCA and mast cells in the four species examined for esterase reaction product. Esterase positive cells were detected, although staining was rather diffuse, with poor localisation of reaction product (Fig. 2). The distribution of stained cells in the four species, however, was similar to that seen after staining with NASDCA (Fig. 2). Sequential staining of NAPNE stained section with alcian blue confirmed the mucosal mast cells identity of these NAPNE stained cells (Fig. 2).

Table 3 Effect of $p H$ on histochemical staining reaction

\begin{tabular}{|c|c|c|c|c|}
\hline \multirow[t]{2}{*}{ Tissue } & \multirow[t]{2}{*}{$p H$} & \multicolumn{3}{|l|}{ Staining } \\
\hline & & $M M C$ & & $C T M C$ \\
\hline \multirow[t]{2}{*}{ Human } & $\begin{array}{l}7 \cdot 1 \\
7 \cdot 5 \\
8 \cdot 0 \\
8 \cdot 5\end{array}$ & $\begin{array}{l}+ \text { to }++ \\
++ \\
+ \\
-\end{array}$ & & $\begin{array}{l}+++ \\
+++ \\
++ \\
-\end{array}$ \\
\hline & & $\mathbf{M M C}$ & GL & CTMC \\
\hline Sheep & $\begin{array}{l}7 \cdot 1 \\
7 \cdot 5 \\
8 \cdot 0 \\
8 \cdot 5\end{array}$ & $\begin{array}{l}- \\
+ \\
-\end{array}$ & $\begin{array}{l}+ \\
++ \\
+ \\
-\end{array}$ & $\begin{array}{l}- \\
- \\
-\end{array}$ \\
\hline
\end{tabular}

Intensity of staining: - no staining, + weak, ++ moderate, +++ intense.

MMC = mucosal mast cells; $C$ TMC = connective tissue mast cells; $\mathrm{GL}=$ globule leucocytes.

Sections from human intestine and infected sheep abomasal tissue previously fixed for $6 \mathrm{~h}$ in $4 \%$ paraformaldehyde were stained with naphthol AS-D chloroacetate dissolved in substrate buffers of different $\mathrm{pH}$. 

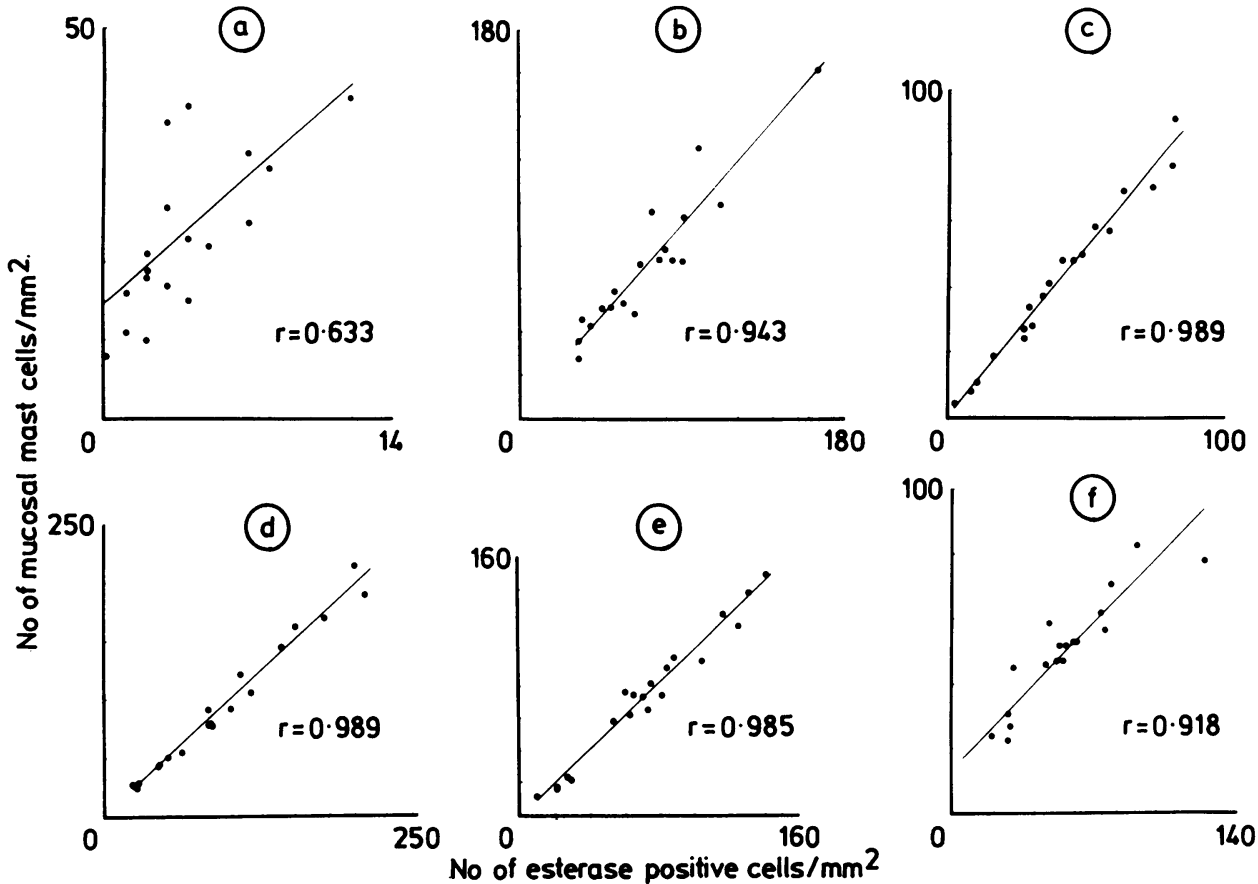

Fig. 4 Comparison by regression analysis of the numbers of cells stained with naphthol AS-D chloroacetate and Fast Garnet GBC salt (number of esterase positive cells $/ \mathrm{mm}^{2}$ ) and of mucosal mast cells/globule leucocytes stained with toluidine blue pH 0.5 (number of mucosal mast cells/mm²) for (a) normal sheep, (b) infected sheep, (c) normal rat, $(d)$ infected rat, $(e)$ infected mouse and $(f)$ human. For (b), (c), (d), (e) and (f), $p<0.001$ (Student's t test) confurmed the mucosal mast cells/globule leucocytes identity of the majority of esterase stained cells. (a) $p<0.01$ (Student's t test), shows that only a proportion of mucosal mast cells in normal sheep were identified as esterase positive.

\section{Discussion}

The enzyme histochemical technique described in this paper showed the presence of chymotrypsin like serine esterases within mucosal mast cells of sheep, mouse, rat, and man. A feature of this technique using the substrate NASDCA was the intense red reaction product seen within the granules of rodent mucosal mast cells and globule leucocytes as well as those of human mucosal mast cells. Although neutrophils of mouse and man also showed weak esterase staining, they were readily distinguished from mucosal mast cells or globule leucocytes, and the enzyme histochemical method described thus provides a sensitive method for the demonstration and enumeration of mucosal mast cells/globule leucocytes.

In normal sheep, however, a smaller proportion of mucosal mast cells was esterase positive when compared with the proportion of stained cells in infected sheep. This may reflect the presence of intragranule serine esterase inhibitors within mucosal mast cells of normal animals, which are inactivated or lost during the immune response induced differentiation of these cells ${ }^{2}$; alternatively, an increase in enzyme synthesis may occur in sheep mucosal mast cells after nematode infection. A further possible explanation is that heterogeneity exists within the sheep mucosal mast cell population, and that esterase containing mucosal mast cells are preferentially differentiated during infection.

Previous studies have shown the presence of esterases within connective tissue mast cells ${ }^{914}$ is and that rodent $t^{40}$ and human ${ }^{5}$ mucosal mast cells differ from connective tissue mast cells in fixation properties. Until now rat mucosal mast cells have been shown satisfactorily only after fixation with acid containing fixatives. ${ }^{4}$ Of interest, therefore, was the present observation that brief immersion of tissues from the four species with $4 \%$ paraformaldehyde provided optimal fixation for enzyme histochemistry and was also adequate for the demonstration of mucosal mast cell glycosaminoglycans. Furthermore, we have recently shown that rat mucosal mast 
cell glycosaminoglycan is optimally preserved by 6 h paraformaldehyde fixation. ${ }^{12}$ Tissues fixed in this manner were stored at $4^{\circ} \mathrm{C}$ for up to two years without any apparent loss of enzyme glycosaminoglycan staining. Aldehyde fixation of mucosal mast cells for $24 \mathrm{~h}$ was less satisfactory in rat, sheep, and human and this may have been a consequence of inactivation of esterase acitivity. For example, prolonged aldehyde fixation may cross link the peripheral proteins for the granule, ${ }^{21} 22$ thus forming a barrier for substrate-enzyme interaction.

NASDCA has been previously used as a histochemical reagent for the localisation of connective tissue mast cells ${ }^{9}$ and is also hydrolysed by chymotrypsin, trypsin, and a variety of esterases. ${ }^{23}$ But the observation in the present study that mucosal mast cell enzymes hydrolysed NAPNE conferred a further degree of specificity to the histochemical reaction, since the hydrolysis of this substrate is restricted to enzymes with a chymotrypsin like subrate specificity..$^{24}$ The rat mucosal mast cell enzyme, RMCPII, has been shown to be a chymotrypsin like serine protease ${ }^{25}$ and the present results would therefore indicate that similar enzymes are also present within mucosal mast cells of sheep, mouse, and man. These chymotrypsin like enzymes may be present in association with other trypsin like enzymes, since the latter have been shown in human connective tissue mast cells $s^{8}$ and pulmonary mast cells ${ }^{26}$ as well as in mouse mastocytoma cells. ${ }^{27}$ Attempts in the present study to characterise further the mucosal mast cell esterases with specific inhibitors were unsuccessful. This failure may reflect the inability of these inhibitors totally to abolish enzyme activity such that residual enzyme may be able to hydrolyse sufficient substrate to form a reaction product indistinguishable from that in controls.

Although there has been controversy over the relation between mucosal mast cells and globule leucocytes, histochemical and ultrastructural studies in both ruminants and rats strongly suggest that globule leucocytes are intraepithelial mucosal mast cells ${ }^{28-31}$ and that mucosal mast cells are derived from bone marrow precursors which differentiate under the influence of $\mathrm{T}$ cell derived interleukin $3 .^{3}$ That the granules of mucosal mast cells and globule leucocytes in infected sheep ${ }^{32}$ and rodents ${ }^{12}$ all contained serine esterases is a further indication of the relation between mucosal mast cells and globule leucocytes. More conclusive evidence for this relation is the recent observation that the granules of rat mucosal mast cells and globule leucocytes contain the mucosal mast cell specific protease RMCPII. ${ }^{33}{ }^{34}$ The latter finding, the present results, and previous observations on isolated ovine mucosal mast cells and globule leucocytes are all in accord with the view that mucosal mast cells and globule leucocytes are of a common lineage $\mathrm{e}^{35}$ and refute the proposition that globule leucocytes develop, sui generis, from an unknown precursor cell. ${ }^{36}$

Although the function of these mucosal mast cell enzymes remains unknown, the presence of similar chymotrypsin like serine esterases within mucosal mast cells of all four species studied suggests an important role for these enzymes, particularly in diseases which feature mucosal mast cell hyperplasia.

We thank Mr Brian Easter and Alan Inglis for the excellent production of photographs. We also thank the surgeons of the Western General Hospital, Edinburgh, for specimens of human intestinal tissue. This work was supported in part by a grant from the Wellcome Trust.

\section{References}

' Bienenstock J, Befus AD, Pearce F, Denburg J, Goodacre R. Mast cell heterogeneity: derivation and function, with emphasis on the intestine. $J$ Allergy Clin Immunol 1982;70:407-12.

2 Jarrett EEE, Haig DM. Mucosal mast cells in vivo and in vitro. Immunology Today 1984;5:115-9.

${ }^{3}$ Enerback L. Mast cells in rat gastrointestinal mucosa 1. Effects of fixation. Acta Pathol Microbiol Scand 1966;66:289-302.

4 Strobel S, Miller HRP, Ferguson A. Human intestinal mucosal mast cells: evaluation of fixation and staining techniques. $J$ Clin Pathol 1981;34:851-8.

s Woodbury RG, Gruzenski GM, Lagunoff D. Immunofluorescent localization of a serine protease in rat small intestine. Proc Natl Acad Sci 1978;75:2785-9.

- King SJ, Miller HRP. Anaphylactic release of mucosal mast cell protease and its relationship to gut permeability in Nippostrongylus-primed rats. Immunology 1984;51:653-60.

7 Woodbury RG, Miller HRP, Huntley JF, Newlands GFJ, Palliser AC, Wakelin D. Mucosal mast cells are functionally active during the spontaneous expulsion of primary intestinal nematode infections in the rat. Nature (in press).

${ }^{8}$ Glenner GG, Cohen LA. Histochemical demonstration of a species specific trypsin-like enzyme in mast cells. Nature 1960; 185:846-7.

' Gomori G. Chloroacetyl esters as histochemical substrates. J Histochem Cytochem 1953;1:469-70.

${ }^{10}$ Miller HRP, Jackson F, Newlands G, Appleyard WT. Immune exclusion, a mechanism of protection against the ovine nematode Haemonchus contortus. Res Vet Sci 1983;35:35763.

"Befus AD, Pearce FL, Gauldie J, et al. Isolation and characteristics of mast cells from the lamina propria of the small bowel. In: Pepys J, Edwards AM, eds. The mast cell its role in health and disease. Tunbridge Wells: Pitman, 1979:702-24.

12 Newlands GFJ, Huntley JF, Miller HRP. Concomitant detection of mucosal mast cells and eosinophils in the intestines of normal and Nippostrongylus-immune rats. A re-evaluation of histochemical and immuno-cytochemical techniques. Histochemistry (in press).

${ }^{13}$ Karnovsky MJ. A formaldehyde-glutaraldehyde fixative of high osmolarity for use in electron microscopy. J Cell Biol 1965;27:137A.

14 Seppa HEJ. Rat skin main neutral protease: immunohisto- 
chemical localization. J Invest Dermatol 1978;71:311-5.

is Lagunoff D, Benditt EP. Histochemical examinations of chymotrypsin-like esterases. Nature 1961;192:1198-9.

${ }^{16}$ Burnstone MS. The cytochemical localization of esterase. J Natl Cancer Inst 1957; 18:167-9.

${ }^{17}$ Enerback L. Mast cells in rat gastrointestinal mucosa. 2. Dyebinding and metachromatic properties. Acta Pathol Microbiol Scand 1966;66:303-12.

${ }^{18}$ Starkey PM. Elastase and cathespin G; the serine proteinases of human neutrophil leucocytes and spleen. In: Barrett AJ, eds. Proteinases in mammalian cells and tissues. Amsterdam: North-Holland Publishing Company, 1977:57-89.

${ }^{19}$ Benditt EP, Arase M. An enzyme in mast cells with properties like chymotrypsin. J Exp Med 1959;110:451-60.

${ }^{20}$ Crowle PK, Phillips DE. Characteristics of mast cells in Chediak-Higashi mice: light and electron microscopic studies of connective tissue and mucosal mast cells. Exp Cell Biol 1983;51:130-9.

${ }^{21}$ Miller HRP, Walshaw $R$. Immune reactions in mucous membranes. IV. Histochemistry of intestinal mast cells during helminth expulsion in the rat. Am J Pathol 1972;69:195-206.

${ }^{22}$ Wingren U, Enerback L. Mucosal mast-cells of the rat intestine: A re-evaluation of fixation and staining properties, with special reference to protein blocking and solubility of the granular glycosaminolycans. Histochem J 1983; 15:571-82.

${ }^{23}$ Rindler R, Hortnagl H, Schmalzl F, Braunsteiner H. Hydrolysis of a chymotrypsin substrate and of naphthol As-D chloroacetate by human leucocyte granules. Blut 1973;26:239-49.

${ }^{24}$ Rindler-Ludwig R, Bretz U, Baggiolini M. Cathepsin G: The chymotrypsin-like enzyme of human polymophonuclear leucocytes. In: Havemann K, Janoff A, eds. Neutral proteases of human polymorphonuclear leukocytes. Baltimore and Munich: Uban and Schwarzenberg, 1978:138-49.

${ }^{25}$ Woodbury RG, Neurath $H$. Structure, specificity and localization of the serine proteases of connective tissues. Febs Lett 1980;114:189-96.

${ }^{26}$ Schwartz LB, Lewis RA, Austen KF. Tryptase from human pulmonary mast cells. Purification and characterization. $J$ Biol
Chem 1981;256: 11939-43.

${ }^{27}$ Vensel WH, Komender J, Barnard EA. Non-pancreatic proteases of the chymotrypsin family. 11 . Two proteases from a mouse mast cell tumour. Biochem Biophys Acta 1971;250:395-407.

${ }^{28}$ Jarrett WFH. Miller HRP, Murray M. The relationship between mast cells and globule leucocytes in parasite infection. Vet $R e c$ 1967;80: 505-96.

${ }^{24}$ Miller HRP, Murray M, Jarrett WFH. Globule leucocytes and mast cells. In: Soulsby EJL, ed. Reaction of host to parasitism. Germany: Elwert Marburg-Lahn, 1967:198-210.

${ }^{30}$ Murray M, Miller HRP, Jarrett WFH. The globule leucocyte and its derivation from the subepithelial mast cell. Lab Invest 1968; 19:222-34.

${ }^{31}$ Miller HRP. Immune reaction in mucous membranes. II. The differentiation of intestinal mast cells during helminth expulsion in the rat. Lab Invest 1971;24:339-47.

${ }^{32}$ Huntley JF, Newlands GFJ, Miller HRP. The isolation and characterization of globule leucocytes: their derivation from MMC in parasitized sheep. Parasite Immunology 1984; 6:371-90.

${ }^{33}$ Woodbury RG, Miller HRP. Quantitative analysis of mucosal mast cell protease in the intestines of Nippostrongylus-infected rats. Immunology 1982;46:487-95.

${ }^{34}$ Huntley JF, McGorum B, Newlands GFJ, Miller HRP. Granulated intraepithelial lymphocytes: their relationship to mucosal mast cells and globule leucocytes in the rat. Immunology (in press).

${ }^{35}$ Miller HRP. The structure, origin and function of mucosal mast cells. A brief review. Biologie Cellulaire 1980;39:229-32.

${ }^{36}$ Ruitenburg EJ, Elgersma A, Lamers CNJ. Kinetics and characteristics of intestinal mast cell and globule leucocytes. In: Pepys J, Edwards AM, eds. The mast cell: its role in health and disease. Tunbridge Wells: Pitman, 1979:732-7.

Requests for reprints to: Dr JF Huntley, Animal Diseases Research Association, Moredun Institute, 408 Gilmenton Road, Edinburgh EH17 7JH, Scotland. 